Jurnal Manajemen dan Bisnis, Volume 2, No. 2, Januari 2021

\title{
KUALITAS PELAYANAN PTSL PADA KANTOR PERTANAHAN / BADAN PERTANAHAN NASIONAL KABUPATEN MAGELANG
}

\author{
Isya Dharma Faristurahman \\ aUniversitas Tidar, S1 Manajemen \\ isyadharma11@gmail.com
}

\begin{abstract}
ABSTRAK
Sebelum adanya PTSL banyak masyarakat yang berpikiran jika mengurus sertifikat tanah membutuhkan waktu yang lama, banyak biaya yang harus dikeluarkan dan ketepatan waktu pengerjaan pegawai kantor yang terkadang molor dan tidak sesuai SOP apalagi juga harus menunggu antrian. Penelitian ini bertujuan untuk menganalisis kualitas pelayanan Percepatan Pendaftaran Tanah Sistematis Lengkap (PTSL) pada Kantor Badan Pertanahan Nasional (BPN) Kabupaten Magelang dalam memberikan pelayanannya kepada masyarakat. Metode penelitian yang digunakan dalam penelitian ini adalah metode deskriptif analisis dengan pendekatan kualitatif. Berdasarkan hasil penelitian ini, dapat di jelaskan bahwa Badan Pertanahan Nasional Kabupaten Magelang sudah cukup baik dalam memberikan pelayanannya secara keseluruhan tetapi masih ada kendala di bagian internal yang perlu diperbaiki untuk kedepannya. Penulis menggunakan lima dimensi Servqual untuk mengetahui kualitas pelayanan Pendaftaran Tanah Sistematis Lengkap (PTSL) yaitu : tangibles, reliability, responsiveness, assurance dan empathy.
\end{abstract}

Kata kunci: Kualitas pelayanan, Dimensi Servqual, PTSL, Badan Pertanahan Nasional

\begin{abstract}
Before the existence of PTSL, many people thought that if it took a long time to take care of land certificates, there were a lot of costs to be incurred and the punctuality of the office staff was sometimes delayed and not in accordance with the SOP, let alone waiting for a queue. This study aims to analyze the quality of service in the Comprehensive Systematic Land Registration (PTSL) at the Office of the National Land Agency (BPN) of Magelang Regency in providing its services to the public. The research method used in this study is a descriptive analysis method with a qualitative approach. Based on the results of this study, it can be explained that the National Land Agency of Magelang Regency is quite good in providing its services as a whole but there are still internal problems that need to be improved in the future. The author uses the five dimensions of Servqual to determine the quality of service in a Complete Systematic Land Registration (PTSL) namely : tangibles, reliability, responsiveness, assurance dan empathy.
\end{abstract}

Keywords: Service quality, Servqual Dimensions, PTSL, National Land Agency 
Jurnal Manajemen dan Bisnis, Volume 2, No. 2, Januari 2021

\section{PENDAHULUAN}

Badan Pertanahan Nasional (BPN) didalam Perpres No. 48 Tahun 2020 pasal 1 \& 2 tentang kedudukan \& tugas Badan Pertanahan Nasional yang selanjutnya disebut BPN adalah Lembaga Pemerintah Non Kementerian yang berada di bawah dan bertanggung jawab kepada Presiden.sesuai dengan Peraturan Presiden Republik Indonesia Nomor 17 Tahun 2015. Yang memiliki tugas melaksanakan tugas pemerintahan di bidang pertanahan sesuai dengan ketentuan peraturan perundangundangan. Di berbagai wilayah di Indonesia sering terjadi sengketa atau ketidakpastian hukum atas tanah, maka dari itu membuktikan pentingnya sertifikat tanah,juga di Indonesia masih lamban dalam proses pendaftaran tanah, maka dari itu Pemerintah Indonesia mengeluarkan sebuah program percepatan pendaftaran tanah sistematis lengkap atau yang disingkat PTSL yang bertujuan untuk mengurangi konflik serta meningkatkan kesejahteraan, kemakmuran dan ekonomi negara. Pengertian PTSL adalah proses pendaftaran tanah untuk pertama kali, yang dilakukan secara serentak dan meliputi semua obyek pendaftaran tanah yang belum didaftarkan di dalam suatu wilayah desa atau kelurahan atau nama lainnya yang setingkat dengan itu. Melalui program ini, pemerintah memberikan jaminan kepastian hukum atau hak atas tanah yang dimiliki masyarakat.

Metode PTSL tertuang dalam intruksi Presiden No 2 tahum 2018 dan Peraturan Pemerintah no 12 tahun 2017 yang bertujuan bahwa untuk memberikan jaminan kepastian hukum dan perlindungan hukum Hak atas Tanah masyarakat secara adil dan merata, serta mendorong pertumbuhan ekonomi negara pada umumnya dan ekonomi rakyat

Maka dari itu perlu adanya analisa mengenai kualitas pelayanan PTSL di BPN khususnya
BPN Kabupaten Magelang. BPN bergerak dibidang pelayanan jasa terkait dengan pengurusan pertanahan. Definisi kualitas menurut Feigenbaum yakni kualitas adalah kepuasan pelanggan sepenuhnya (full customer satisfaction). Suatu produk dapat berkualitas apabila dapat memberi kepuasan sepenuhnya kepada konsumen yakni sesuai dengan apa yang diharapkan konsumen atas suatu produk, sedamgkan Pelayanan menurut Kasmir (2008) merupakan kemampuan yang dimiliki oleh seseorang dalam memberikan pelayanan dengan standar yang telah ditentukan yang dapat memberikan kepuasan pelanggan..Kepuasan pelanggan dibidang jasa merupakan suatu keharusan bagi suatu bisnis untuk sukses. Keunggulan dari bisnis jasa yang dapat diandalkan yaitu dari segi kualitas pelayanannya. Pelayanan publik berdasarkan Undang-undang No. 25 Tahun 2009 adalah kegiatan atau rangkaian kegiatan dalam rangka pemenuhan kebutuhan pelayanan sesuai dengan peraturan perundang- undangan bagi setiap warga negara dan penduduk atas barang, jasa, atau pelayanan administratif yang disediakan oleh penyelenggara pelayanan publik

Kualitas pelayanan dapat diukur dengan menggunakan metode dan sistem yang sesuai dengan standar baku pelayanan publik. Terdapat lima dimensi dalam penilaian kualitas pelayanan yaitu :

1. Tangibles (bukti terukur), menggambarkan apa yang terlihat secara fisik, perlengkapan, dan penampilan dari personality serta kehadiran para pengguna

2. Reliability (keandalan), merujuk kepada kemampuan untuk memberikan pelayanan yang disampaikan secara akurat dan handal..

3. Responsiveness (daya tanggap), yaitu kesediaan karyawan untuk 
Jurnal Manajemen dan Bisnis, Volume 2, No. 2, Januari 2021

membantu pelanggan serta memberikan perhatian yang cepat dan tepat.

4. Assurance (jaminan), merupakan sikap yang santun dan memiliki pengetahuan luas yang dapat memberikan rasa percaya serta keyakinan.terhadap konsumen

5. Empathy (empati), mencakup kepedulian serta perhatian pribadi kepada para pelanggan

Kualitas dari pelayanan yang baik dapat dilihat dari tingkat kepuasan konsumen yang berarti konsumen mendapatkan pelayanan yang sesuai dengan yang diharapkan konsumen atau bahkan lebih dari yang diharapkan konsumen. Maka dari itu, sangat penting bagi BPN Kabupaten Magelang untuk memberikan pelayanan yang terbaik dengan melayani sepenuhnya para konsumen yang ingin mendapatkan sertifikat khususnya yang melalui program pemerintah yaitu program PTSL, yang akan dianalisis oleh penulis berdasarkan dimensi Servsqual atau service quality atau yang biasa disebut kualitas pelayanan.

\section{METODE}

Metode penelitian yang digunakan oleh penulis dalam penelitian ini yaitu metode deskriptif analisis dengan pendekatan kualitatif. Teknik pengumpulan data dalam penelitian ini menggunakan teknik observasi, wawancara dan studi literatur. Jenis data yang dihasilkan adalah data primer, yaitu data yang didapatkan secara langsung oleh sumber aslinya.

\section{HASIL DAN PEMBAHASAN}

Berdasarkan penelitian yang telah penulis lakukan mengenai kualitas pelayanan PTSL di BPN Kabupaten Magelang, hasil penelitian dijabarkan melalui dimensi Servqual sebagai berikut :

1. Tangibles (Bukti Terukur)
Terkait dengan daya tarik, meliputi fasilitas fisik, perlengkapan pegawai, dan kondisi fasilitas penunjang, serta penampilan pegawai terhadap kualitas pelayanan PTSL. Keadaan didalam Kantor BPN Kabupaten Magelang, kantor pelayananannya sudah lumayan baik serta adanya mesin pencetak nomor antrian yang dihubungkan ke layar monitor untuk membantu memudahkan pelanggan dalam menunggu nomor antrian sesuai dengan pelayanan yang diinginkan konsumen, jadi pelanggan tidak hanya menunggu giliran untuk dipanggil, dan juga adanya komputerisasi yang memudahkan pegawai PTSL dalam mengakses informasi mengenai berkas sertifikat yang akan, sedang dan telah diproses, perlengkapan pegawai PTSL sudah cukup baik hal yang penting untuk pegawai PTSL adalah komputer dan ponsel karena untuk berkomunikasi yang dimana tiap pegawai pasti memiliki handphone, dari penampilan pegawai juga menarik \& sudah sesuai dengan yang ditentukan kantor, rapi dan berseragam.

2. Reability (Keandalan)

Untuk kemampuan dan keandalan dari pegawai di BPN Kabupaten Magelang sudah baik karena dapat melayani dengan cepat dan tepat professional sesuai dengan bidang yang dikerjakan, tetapi karena program TPSL oleh pemerintah sehingga berkas fisik banyak yang di input ke computer terkadang terdapat berkas yang didalamnya kurang lengkap dan menjadi keluhan pelanggan itupun terkait dengan proses input yang pegawainya diberi deadline dan berkas yang menumpuk setiap harinya sehingga membuat 


\section{Jurnal Manajemen dan Bisnis, Volume 2, No. 2, Januari 2021}

pegawai kurang focus dalam menginput berkas fisik ke computer. Sehingga pegawai yang menginput data terkesan terburu buru dalam mengerjakan, walaupun hal tersebut sudah dibantu oleh mahasiswa atau siswa smk yang sedang melakukan magang tetapi tetap sulit dalam menginput karena banyaknya berkas dan terdapat berkas lama yang tulisannya hampir tidak dapat terbaca.

3. Responsiveness (Daya Tanggap)

Terkait dengan aspek ini pegawai di Kantor BPN Kabupaten Magelang dalam hal memberikan kesediaan dan timbal balik pada konsumen sudah baik karena dapat sesuai dengan harapan pelanggan dengan membalas keluhan pelanggan dengan sopan dan menjelaskannya secara baik. dan terbuka sesuai dengan keadaan aslinya. Dapat dengan siap sedia membantu konsumen yang memiliki urusan terkait PTSL.

4. Assurance (Jaminan)

Terkait pada sikap pegawai yang santun dan dapat memberikan rasa kepercayaan terhadap pelanggan, seorang pegawai harus bersikap sabar dan sopan dalam menanggapi para pelanggan agar dapat menyesuaikan apa yang diharapkan oleh pelanggan, juga harus memiliki pengetahuan yang cukup baik dalam bidang yang sedang dikerjakan, terkait dengan hal ini pegawai di BPN Kabupaten Magelang terkadang kurang tepat waktu dalam hal melayani pelanggan dikarenakan terkadang petugas sedang mengurusi hal lain sehingga membuat pelanggan menunggu kedatangan petugas tersebut. Dan juga ketika sudah akan tutup jam kerja tetapi urusan yang sedang dikerjakan belum dapat diselesaikan, juga kendala pada berkas yang kurang lengkap itu terkadang tidak dapat diselesaikan karena harus mengikuti prosedur yang ada pada hari itu para pelanggan dimohon untuk kembali keesokan harinya. Juga jumlah pelanggan yang tidak menentu dan kurangnya jumlah pegawai menjadi kendala dalam pengerjaan hal tersebut jadi itu merupakan kendala yang wajar dihadapi. Terkait dengan Jaminan legalitas, masyarakat sudah percaya karena BPN berada dibawah naungan pemerintah dan diawasi oleh hukum. Masyarakat juga tidak khawatir dengan biaya yang harus dibayarkan karena dengan adanya kebijakan PTSL ini, masyarakat khususnya bagi golongan ekonomi lemah dibebaskan dari kewajiban membayar (gratis) sesuai dengan kebijakan yang dikeluarkan oleh pemerintah Indonesia Program tersebut dituangkan dalam Peraturan Menteri No 12 tahun 2017 tentang PTSL dan Instruksi Presiden No 2 tahun 2018.

5. Empathy (Empati)

Terkait dengan empati atau kepedulian dan perhatian pribadi kepada para pelanggan, para pegawai di kantor BPN Kabupaten Magelang memiliki rasa empati yang cukup baik terbukti dengan sikapnya dalam melaksanakan tugas sesuai prosedur dan juga dengan baik memahami keluhan yang dialami pelanggan dan mencari solusi atau jalan keluar yang paling baik dalam menghadapi suatu persoalan. PTSL dalam melakukan pelayanan kepada pemohon. Pemohon mengharapkan sikap yang dapat saling mengerti, peduli, teliti, sopan serta ramah antara petugas dan 
Jurnal Manajemen dan Bisnis, Volume 2, No. 2, Januari 2021

pemohon disemua instansi pemerintah sebagai pelayan public dan itu sudah cukup baik di BPN Kabupaten Magelang.

\section{KESIMPULAN}

Kesimpulan yang penulis ambil dari hasil penelitian yang dilakukan yaitu terkait dengan dimensi yang pertama yaitu dimensi tangibles di Kantor BPN Kabupateng Magelang sudah cukup baik dibuktikan dengan kelengkapan fasilitas pegawai dan kantor yang memadai dan juga menghasilkan kemudahan untuk para pelanggan, dimensi yang kedua yaitu reliability sudah cukup baik hanya terkadang masih terdapat kendala berupa keluhan kelengkapan berkas, dimensi yang ketiga yaitu Responsiveness sudah cukup baik dan sesuai dengan harapan pelanggan dengan menjawab keluhan keluhan secara apa adanya, dimensi yang keempat yaitu assurance, di bidang hukum sudah cukup baik karena tercantum dalam Peraturan Menteri No 12 tahun 2017 tentang PTSL dan Instruksi Presiden No 2 tahun 2018, tetapi kurang dalam pelaksanaan karena terdapat kendala dari faktor internal dan dimensi yang kelima yaitu empathy sudah cukup baik karena dapat meyesuaikan harapan pelanggan yaitu sopan, ramah, dan saling mengerti.

\section{SARAN}

Saran yang dapat penulis berikan untuk menyelesaikan kendala yang terdapat di bagian internal kantor seperti kekurangan waktu yaitu dengan menambah jumlah pegawai tidak tetap atau hanya sementara yang dibayar harian demi menciptakan keefisienan dalam waktu pengerjaan, yang di gaji per hari tetapi dari segi pelayanan kantor BPN Kota Magelang dikatakan sudah cukup baik 
Jurnal Manajemen dan Bisnis, Volume 2, No. 2, Januari 2021

\section{DAFTAR PUSTAKA}

Kasmir. 2008. Etika Costumer Service. Jakarta:

Raja Gravindo Persada.

Moleong, L. 2007. Metodologi Penelitian

Kualitatif. Bandung: PT.Remaja Rosda Karya.

Nurhasari, Wijiati. 2013. Pengelolaan Pembelajaran Tari Di Sanggar Family Sukajadi Bandung. S1 thesis, Universitas Pendidikan Indonesia.

Tjiptono, F. \& Chandra, G. 2005. Service, Quality And Satisfaction. Yogyakarta: Andi Offset.

Tjiptono, Fandy. 2007. Pemasaran Jasa Edisi Pertama: Cetakan Ketiga. Penerbit Bayumedia Publising. Malang.

Dokumen Resmi Pemerintah :

Pemerintah Indonesia, 2013. Peraturan Presiden Nomor 48 Tahun 2020 Tentang Badan Pertanahan Nasional Republik Indonesia

Pemerintah Indonesia, 2015. Peraturan Presiden Republik Indonesia Nomor 17 Tahun 2015 Tentang Kementerian Agraria Dan Tata Ruang

Pemerintah Indonesia, 2017. Peraturan Menteri Agraria Dan Tata Ruang / Kepala Badan Pertanahan Nasional Republik Indonesia Nomor 12 Tahun 2017 Tentang Percepatan Pendaftaran Tanah Sistematis Lengkap

Pemerintah Indonesia, 2018. Instruksi Presiden Nomor 2 Tahun 2018 Tentang Percepatan Pendaftaran Tanah Sistematis Lengkap Di Seluruh Wilayah Republik Indonesia

Pemerintah Indonesia, 2018. Peraturan Menteri Agraria Dan Tata Ruang / Kepala Badan Pertanahan Nasional Republik Indonesia Nomor 6 Tahun 2018 Tentang Pendaftaran Tanah Sistematis Lengkap 